\title{
Shallow water heterobranch sea slugs (Gastropoda: Heterobranchia) from the Región de Atacama, northern Chile
}

Juan Francisco Araya, Ángel Valdés

The coast of northern Chile has been sparsely studied in regards to its invertebrate fauna, with just a few works reviewing the distribution of local mollusks. This work presents a survey of the shallow water heterobranch sea slugs currently occurring around the port of Caldera (27은, in the Región de Atacama, northern Chile. Eight species of sea slugs were found in this study: Aplysiopsis cf. brattstroemi (Marcus, 1959), Baptodoris peruviana (d'Orbigny, 1837), Diaulula variolata (d'Orbigny, 1837), Doris fontainii d'Orbigny, 1837, Onchidella marginata (Couthouy in Gould, 1852), Phidiana lottini (Lesson, 1831), Tyrinna delicata (Abraham, 1877) and the new species Berthella schroedli sp. nov., described herein. All of the species found in the area are endemic to South America, having distributions in the southeastern Pacific and South Atlantic Oceans, from Ancash, Perú to Peninsula Valdés, Argentina, and two of them represent species which are endemic to the Chilean coasts (Aplysiopsis cf. brattstroemi and Berthella schroedli). The finding of a previously undescribed species emphasizes the need of further surveys, particularly in subtidal and deeper waters, in order to improve the knowledge on this neglected fauna in Atacama. 


\section{Shallow water heterobranch sea slugs (Gastropoda:}

\section{Heterobranchia) from the Región de Atacama, northern Chile}

3 Juan Francisco Araya ${ }^{1}$, Ángel Valdés ${ }^{2}$

$4{ }^{1}$ Departamento de Geología, Universidad de Atacama, Copiapó, Chile and Programa de Doctorado en

5 Sistemática y Biodiversidad, Universidad de Concepción, Concepción, Chile.

$6{ }^{2}$ Department of Biological Sciences, California State Polytechnical University, Pomona, California, USA.

7

8 Corresponding Author:

9 Juan Francisco Araya $^{1}$

10 Departamento de Geología, Universidad de Atacama, Copayapu 485, Copiapó, Región de Atacama, Chile

11 Email address: jfaraya@u.uchile.cl

Shallow water heterobranch sea slugs (Gastropoda: Heterobranchia) from the Región de Atacama, northern Chile 
${ }^{1}$ Departamento de Geología, Universidad de Atacama, Copayapu 385, Copiapó, Chile and

Programa de Doctorado en Sistemática y Biodiversidad, Universidad de Concepción, Concepción, Chile.E-mail address: jfaraya@u.uchile.cl

orcid.org/0000-0002-4087-9641

urn:lsid:zoobank.org:author:443B4F42-FB13-42A6-B92B-1B0F835698A9

${ }^{2}$ Department of Biological Sciences, California State Polytechnic University, 3801 West Temple Avenue, Pomona, California 91768-4032, USA.

urn:lsid:zoobank.org:author:B5F56B28-F105-4537-8552-A2FE07E945EF

\section{ABSTRACT}

The coast of northern Chile has been sparsely studied in regards to its invertebrate fauna, with just a few works reviewing the distribution of local mollusks. This work presents a survey of the shallow water heterobranch sea slugs currently occurring around the port of Caldera $\left(27^{\circ} \mathrm{S}\right)$, in the Región de Atacama, northern Chile. Eight species of sea slugs were found in this study: Aplysiopsis cf. brattstroemi (Marcus, 1959), Baptodoris peruviana (d'Orbigny, 1837), Diaulula variolata (d'Orbigny, 1837), Doris fontainii d'Orbigny, 1837, Onchidella marginata (Couthouy in Gould, 1852), Phidiana lottini (Lesson, 1831), Tyrinna delicata (Abraham, 1877) and the new species Berthella schroedli sp. nov., described herein. All of the species found in the area are endemic to South America, having distributions in the southeastern Pacific and South Atlantic Oceans, from Ancash, Perú to Peninsula Valdés, Argentina, and two of them represent species which are endemic to the Chilean coasts (Aplysiopsis cf. brattstroemi and Berthella schroedli). The finding of a previously undescribed species emphasizes the need of further surveys, particularly in subtidal and deeper waters, in order to improve the knowledge on this neglected fauna in Atacama.

\section{INTRODUCTION}

The mollusks of the Región de Atacama, in northern Chile, have been sparsely studied; most of the species commonly present in the area were described in the nineteenth century (Broderip \& Sowerby, 1832; Sowerby, 1832, 1833; d'Orbigny, 1835-1847; Gould, 1852; Hupé in Gay, 1854, among others), with a few works reviewing species during the past century (Dall, 
63

64

65

66

67

68

69

1909; Gigoux, 1932, 1934; Rehder, 1945) and, more recently, with several works describing new species (Osorio, 2012; Araya, 2013, 2015a, 2015b; Miquel \& Araya, 2013; Collado, 2015; Araya \& Reid, 2016) or giving new records (Araya \& Araya, 2015a). Regarding heterobranch sea slugs in particular (sensu Camacho-García et al. (2014) and Padula et al. (2014)), only the studies by Bergh (1898), Marcus (1959), Schrödl (1996a, 1996b, 1997, 2003), Fischer, van de Velde \& Roubos (2007) and most recently Labrín, Guzmán \& Sielfeld (2015) have included species from northern Chile. However, a few recent papers dealing with the Peruvian fauna, including some species commonly found in Chilean waters (e.g., Millen et al. 1994; Nakamura 2006, 2007; Martynov \& Schrödl 2011; Uribe \& Pacheco, 2012; Uribe et al. 2013; Schrödl \& Hooker, 2014 and others), have also contributed to the knowledge of this group in the southeastern Pacific.

The present study provides records of sea slugs found in shallow waters around Caldera $\left(27^{\circ} \mathrm{S}\right)$, Región de Atacama, northern Chile. The coast of this area consists of rocky formations with sparse sandy beaches and a comparatively narrow intertidal zone. Rocky platforms, boulder fields and intertidal pools are common; however some sheltered areas have open sandy beaches, usually exposed to strong surf. All of the species reviewed in this work are endemic to southern South America; with two of them presenting new distributional records in Chile (Table 1). The aim of this preliminary study is to contribute to the knowledge of the molluscan fauna in Chile, particularly from the largely neglected northern coasts.

\section{MATERIALS AND METHODS}

The material examined was collected in the summers of 2010, 2011 and 2012 in diverse locations near the port of Caldera $\left(27^{\circ} \mathrm{S}\right)$, Region of Atacama, northern Chile. All the collecting was made manually in the intertidal areas, mostly on rocky outcrops and tidal pools. The specimens were deposited in the collections of the Museo de Paleontología de Caldera (MPCCL), Caldera, Chile; Museo de Zoología de la Universidad de Concepción (MZUC), Concepción, Chile, California State Polytechnic University Invertebrate Collection (CPIC), Pomona, USA, and in the collection of the Natural History Museum of Los Angeles County Museum (LACM), Los Angeles, USA. Field study permits were not required for this study and none of the species studied herein are currently under legal protection. All the collected specimens were preserved in $95 \%$ ethanol. Photographs of living animals were taken with a 
94 Canon A530 digital camera and a 10x geologic loupe. All sizes given are living measurements, radular features were examined by scanning electron microscopy (SEM). Color plates were composed with basic image programs and colors of the images were not modified.

In order to characterize genetically and barcode the new species of Berthella, DNA extraction was performed using a hot Chelex ${ }^{\circledR}$ protocol. Approximately 1-3 mg tissue was taken from one animal and cut into fine pieces for extraction, the tissue was rinsed and rehydrated using $1.0 \mathrm{~mL}$ TE buffer (10 mM Tris, $1 \mathrm{mM}$ EDTA, $\mathrm{pH} 8.0)$ for 20 minutes. A 10\% (w/v) Chelex ${ }^{\circledR} 100$ (100-200 mesh, sodium form, Bio-Rad) solution was prepared using TE buffer. After rehydration, the mixture was then centrifuged, $975.00 \mathrm{~mL}$ of the supernatant was removed, and $175.00 \mathrm{~mL}$ of the Chelex® solution was added. Samples were then incubated at $56^{\circ} \mathrm{C}$ in a water bath for 20 minutes, heated to $100^{\circ} \mathrm{C}$ in a heating block for 8 minutes, and the supernatant was used for PCR. Folmer's universal COI primers (Folmer et al. 1994) were used to amplify the region of interest for one specimen. The master mix (for each sample) was prepared using 34.75 $\mu \mathrm{L} \mathrm{H2O,} \mathrm{5.00} \mu \mathrm{L}$ PCR Buffer (ExACTGene, Fisher Scientific), $5.00 \mu \mathrm{L} 25 \mathrm{mM} \mathrm{MgCl2,} 1.00 \mu \mathrm{L}$ $40 \mathrm{mM}$ dNTPs, $1.00 \mu \mathrm{L} 10 \mu \mathrm{M}$ primer $1,1.00 \mu \mathrm{L}$ primer $2,0.25 \mu \mathrm{L} 5 \mathrm{mg} / \mathrm{mL}$ Taq, and $2.00 \mu \mathrm{L}$ extracted DNA. Reaction conditions were an initial denaturation for $3 \mathrm{~min}$ at $95^{\circ} \mathrm{C}, 39$ cycles of 1) denaturation for $45 \mathrm{sec}$ at $94^{\circ} \mathrm{C}, 2$ ) annealing for $45 \mathrm{sec}$ at $45^{\circ} \mathrm{C}$, and 3) elongation for $2 \mathrm{~min}$ at $72^{\circ} \mathrm{C}$, and a final elongation for $10 \mathrm{~min}$ at $72^{\circ} \mathrm{C}$. PCR products yielding bands of appropriate size (approximately $695 \mathrm{bp}$ ) were purified using the Montage PCR Cleanup Kit (Millipore). Cleaned PCR samples were quantified using a NanoDrop 1000 Spectrophotometer (Thermo Scientific). Sequencing was outsourced to Source Bioscience (Santa Fe Springs, California). The sequence was assembled and edited using Geneious Pro 8.1.7 (Kearse et al. 2012). Geneious was also used to extract the consensus sequence, which was 658 bp long and is deposited in GenBank (GenBank Voucher Nbr KU551261).

The electronic version of this article in Portable Document Format (PDF) will represent a published work according to the International Commission on Zoological Nomenclature (ICZN), and hence the new names contained in the electronic version are effectively published under that Code from the electronic edition alone. This published work and the nomenclatural acts it contains have been registered in ZooBank, the online registration system for the ICZN. The ZooBank LSIDs (Life Science Identifiers) can be resolved and the associated information viewed through any standard web browser by appending the LSID to the prefix http://zoobank.org/. The 
125 LSID for this publication is: urn:Isid:zoobank.org:pub:088D994A-9E1E-4324-A6DF-

126 FCCC2B0E3437. The online version of this work is archived and available from the following

127 digital repositories: PeerJ, PubMed Central and CLOCKSS.

128

129 RESULTS

130 Systematics

131 Heterobranchia

132 Order Nudibranchia Cuvier, 1817

133 Superfamily Aeolidioidea Gray, 1827

134 Family Facelinidae Bergh, 1889

135 Genus Phidiana Gray, 1850

136 Type species Eolidia patagonica d'Orbigny, 1836, by subsequent designation by Alder \&

137 Hancock (1855).

138

139 Phidiana lottini (Lesson, 1831)

140 (Fig. 1A)

141 Eolidia lottini Lesson, 1831: 290, pl. 14, fig. 6. Cavolina lottini d'Orbigny, 1837: 194. Phidiana

142 inca Gray, 1850: 108; Bergh, 1867: 100, pl. 3, figs. 1-13; Marcus, 1959: 79, figs. 184-190;

143 Álamo \& Valdivieso, 1997: 85. Phidiana lottini Schrödl, 1996a: 41, pl. II, fig. 13. pl. VII, fig.

144 41; Schrödl, 2003: 83, figs. 51, 63, 64, 88; Schrödl, 2009: 539; Schrödl et al. 2005: 7, pl. 2, fig.

145 17; Uribe et al. 2013: 52, fig. 3J; Schrödl \& Hooker, 2014: 54, figs. 12, 13. Uribe et al. 2014:

146 167. A detailed chresonymy can be found in Schrödl (2003).

147 Material examined: Two specimens collected in a tidal pool in rocky outcrops, Playa Brava 148 (2703' S; 7049’ W), Caldera, Región de Atacama, Chile (MZUC 39608); and one specimen 149 collected inside an empty Austromegabalanus psittacus shell in Calderilla (2705’ S; 7050’ W), 150 Caldera, Región de Atacama, Chile (MPCCL 90216A).

151 Diagnosis: Elongate body of silky white to sometimes reddish color, covered by 20-26 parallel 152 rows of conspicuously colored cerata. Dorsum with a fine longitudinal white line. Cerata with 153 bands of brown and orange at base and with bright whitish tips. Rhinophores annulate, yellowish 154 white. Oral tentacles long and pinkish-white. Anterior foot corners slightly extended. 
155 Distribution: Phidiana lottini has been recorded in Chile from Punta Blanca, Arica (18²9' S; $\left.15670^{\circ} 20^{\prime} \mathrm{W}\right)$ to the Guaitecas Islands (44 S), southern Chile (Schrödl, 2003; Schrödl \& Hooker 157 2014). This species has also been recorded from Ancash, Isla Santa, Lima, and Callao (1202' S), 158 central Peru (Uribe et al. 2013; Schrödl \& Hooker, 2014).

159 Remarks: Phidiana lottini is easily recognizable from other aeolid sea slugs found in northern 160 Chile because of the cerata arranged in parallel rows and the presence of a white dorsal line 161 between the rhinophores. This is a comparatively common nudibranch in the area, usually found 162 in protected localities. Egg masses of this species are loosely coiled whitish spiral ribbons, of 163 about $30 \mathrm{~mm}$ in diameter (see Schrödl, 2003).

164

\section{Superfamily Doridoidea}

Family Chromodorididae Bergh, 1891

Genus Tyrinna Bergh, 1898

Type species Tyrinna nobilis Bergh, 1898 (= Tyrinna delicata (Abraham, 1877)), by monotypy. 169

Tyrinna delicata (Abraham, 1877)

(Fig. 1B)

172

Doris delicata Abraham, 1877: 211, pl. XXX, figs. 20-22. Tyrinna nobilis Bergh, 1898: 523, pl. 30, figs. 21-29, pl. 32, figs. 21-24; Marcus, 1959: 31, figs. 45-53; Muniaín, Valdés \& Ortea, 1996: 265, figs. 2-6; Schrödl, 1996a: 22, pl. 3, fig. 15; 1997: 41; Schrödl, 2003: 31, figs. 15, 70; Schrödl et al. 2005: 4, pl. 1, fig. 8; Schrödl \& Millen, 2001: 1146, figs. 1-6; Schrödl, 2009: 521; Aldea, Césped \& Rosenfeld, 2011: 43, fig. 3C. Uribe et al. 2013: 48, fig. 2A. Tyrinna pusae Marcus, 1959: 33, figs. 54-64. A detailed chresonymy can be found in Schrödl (2003)

Material examined: One specimen collected under rocks at low tide, in tidal pools in rocky outcrops, South of Obispito (26\%45'51” S; 7045’07” W), Caldera, Región de Atacama, Chile (MPCCL 90216B).

Diagnosis: Body oval-elongate, translucent-whitish, with opaque white lines surrounding the edges of foot and mantle. Dorsum smooth, with irregular and submarginal rows of orange spots, absent from the central region of mantle. Oral tentacles longitudinally enrolled. Anterior part of foot bilabiate, forming a thick lip. Posterior end of the foot extending beyond the mantle in crawling individuals (See Uribe et al. (2013) for a more complete description). 
186 Distribution: From Isla Blanca $\left(09^{\circ} \mathrm{S}\right)$, Ancash, Peru to Peninsula Valdés, in the Atlantic

187 Magellan Strait (Schrödl \& Millen 2001; Uribe et al. 2013). This species has been also recorded 188 in the Juan Fernández Islands, off central Chile.

189 Remarks: Tyrinna delicata is clearly distinguishable from other nudibranchs in northern Chile 190 by the submarginal dorsal rows of orange spots, which are very visible in the translucent whitish 191 mantle. This species, having a complex synonymy, was listed as Tyrinna nobilis until recent, 192 however the discovery of the holotype of Tyrinna delicata (Abraham, 1877) by Schrödl \& 193 Millen (2001) gave priority to the latter name.

194

195

196

Family Discodorididae Bergh, 1891

Genus Baptodoris Bergh, 1884

197

Type species Baptodoris cinnabarina Bergh, 1884, by monotypy.

198

\section{Baptodoris peruviana (d'Orbigny, 1837)}

200 (Fig. 1C)

201

Doris peruviana d'Orbigny, 1837: 188, pl. XV, figs. 7-9. Doriopsis peruviana Dall, 1909: 203.

202

Platydoris punctatella Bergh, 1898: 521, figs 12-20; Dall, 1909: 203; Schrödl, 1996a: 23, pl. IV, fig. 27. Dendrodoris peruviana Álamo \& Valdivieso, 1997: 85. Platydoris peruviana Schrödl, 2003: 34, figs. 17, 54, 71. Baptodoris peruviana Fischer \& Cervera, 2005a: 515, figs. 1-8. Uribe et al. 2013: 51, fig. 3D. Baptodoris? peruviana Schrödl \& Hooker, 2014: 48, fig. 4.

Material examined: One specimen collected under rocks at very low tide, Playa Ramada

207 (2700’ S; 7048’ W) Caldera, Región de Atacama, Chile (MZUC 39607).

Diagnosis: Elevated, oval and slightly convex white-yellowish body, with minute brown spots over the notum which is densely covered by very small rounded caryophyllidia. Rhinophores and gills hyaline white, not elevated. Rhinophores are perfoliate with 7-10 lamellae. The branchial tuft consists of 6 uni-bipinnate gills, which form a circle around the anus at the posterior end of the body. Ventrally, the head is small with short digitiform oral tentacles. The foot is narrow, with the anterior edge notched at the mid-line and grooved. The notal margin is white and wider than the foot (See Fischer \& Cervera (2005a) for a complete description).

215 Distribution: According to Fischer \& Cervera (2005a), this species has been recorded from South of San Lorenzo Island, Lima, Peru to Valparaiso, $\left(33^{\circ} 02^{\prime} \mathrm{S} ; 7^{\circ} 38^{\prime} \mathrm{W}\right)$ Chile. 
218 Genus Diaulula Bergh, 1884

219 Type species Doris sandiegensis (Cooper, 1863), by monotypy.

220

221 Diaulula variolata (d'Orbigny, 1837)

222 (Fig. 1D)

223 Doris variolata d'Orbigny, 1837: 186, pl. 16, figs. 1-3. Anisodoris marmorata Marcus, 1959:

224 45, figs. 98-103; Schrödl, 2003: 41, figs. 21, 57, 75; Fischer \& Cervera, 2005b: 174. Uribe et al.

225 2013: 48, fig. 2B. Anisodoris marmorata Bergh, 1898: 515, pl. 30, figs. 5-7 (non Archidoris

226 marmorata Bergh, 1881); Marcus, 1959: 45, figs. 98-103. Anisodoris rudberghi Marcus \&

227 Marcus, 1967: 69; Schrödl, 1996: 25, pl. IV, figs. 21-22. Peltodoris marmorata Valdés \&

228 Muniaín, 2002: 349, figs. 1D, 4, 5. A detailed chresonymy can be found in Schrödl (2003: 39)

229 Material examined: One specimen collected under rocks at very low tide, North of Obispito

230 (26² $\left.45^{\prime} \mathrm{S} ; 7^{\circ} 45^{\prime} \mathrm{W}\right), 40 \mathrm{~km}$ N of Caldera, Región de Atacama, Chile (MZUC 39606).

231 Diagnosis: Whitish-yellowish body with minute black spots over the notum, which is densely

232 covered by small and narrow caryophyllidia. Wide free mantle rim. Rhinophoral and branchial

233 sheaths elevated, covered with caryophyllidia. Six to seven gills, ramified up to four-five times.

234 Oral tentacles long and digitiform. Foot bilabiate, with upper lip notched. Lip cuticle smooth.

235 Rhinophores have more than 15 lamellae (See Schrödl, (2003) for a complete description).

236 Distribution: This species has been recorded in Chile from Arica $\left(18^{\circ} \mathrm{S}\right)$ to the Bahía de San

237 Vicente $\left(36^{\circ} \mathrm{S}\right)$, and most recently from Ica, Perú (Uribe et al. 2013).

238

239

240 Genus Doris Linnaeus, 1758

Family Dorididae Rafinesque, 1815

241

Type species Doris verrucosa Linnaeus, 1758, by monotypy.

242

Doris fontainii d'Orbigny, 1837

244 (Fig. 2A)

Doris fontainii d'Orbigny, 1837: 189, pl. 15, figs. 1-3. Anisodoris fontaini Odhner, 1926: 85, 246 figs. 70-72, pl. 3, figs. 47-49; Schrödl, 1996a: 24, pl. III, fig. 19; Schrödl, 2000b: 73, fig. $2-3$. 
248 et al. 2013: 51, fig. 3E; Schrödl \& Hooker, 2014: 47, fig. 2. Archidoris fontaini Schrödl, 2003:

249 45, figs. 24, 58, 76; Schrödl, 2009; Schrödl et al. 2005: 4, pl. 2, fig. 9; Schrödl \& Grau, 2006: 5, 250 fig. $2 \mathrm{~A}-\mathrm{B}$.

251 Material examined: One specimen collected in a tidal pool at Playa El Jefe (27 03'46" S;

252 7049’ W), Caldera, Región de Atacama, Chile (MZUC 37642).

253 Diagnosis: Orange to brownish body coloration, with a highly arched and large body (up to 10

$254 \mathrm{~cm}$ according to Schrödl \& Hooker (2014)). Notum covered with many small (up to $5 \mathrm{~mm}$ in

255 diameter) rounded tubercles. Five to seven tri- to quadripinnate gills. Gills and rhinophores

256 surrounded by elevated sheaths with small tubercles. Oral tentacles triangular, grooved. Foot

257 broad, anteriorly bilabiate and notched. Lip cuticle smooth (See Schrödl (2003) for a complete

258 description).

259 Distribution: This species has been recorded from Ancash, Islote Ferrol, Peru (Uribe et al.

260 2013) to northern Argentina (Valdés \& Muniaín, 2002).

261 Remarks: This species is easily recognizable due to its large size, brilliant orange body color

262 and a mantle covered with conspicuous rounded tubercles. Of the examined specimens, none had

263 the dark brown pigment between the tubercles, which Schrödl et al. (2005), regarded as

264 characteristic of central and northern Chilean specimens. This was the most common species in

265 the area; they are usually found in the subtidal zone but specimens were also collected from tidal

266 pools at low tide. According to some commercial divers this species is common below $3 \mathrm{~m}$ depth

267 near Bahía Inglesa $\left(27^{\circ} 07^{\prime} \mathrm{S} ; 7^{\circ} 52^{\prime} \mathrm{W}\right)$, south of Caldera.

268

269

Order Pleurobranchomorpha Schmekel, 1985

270

Superfamily Pleurobranchoidea Gray, 1827

271 Family Pleurobranchidae Gray, 1827

272

Genus Berthella Blainville, 1824

273

Type species Bulla plumula Montagu, 1803, by original designation.

274

275

Berthella schroedli sp. nov.

276

urn:1sid:zoobank.org:act:9F1D698F-96FB-40B0-A972-3C1F6F15014C

277

(Figs. 3A-C, 4A-D, 5A-B, 6C) 
278 Type material: Holotype MPCCL 90216C, paratypes: LACM 3327 (4 specimens), MPCCL

$27990216 \mathrm{D}$ (4 specimens); other material: CPIC 000827 (5 specimens). All the type material

280 collected at the type locality and preserved in ethanol $96 \%$.

281 Type locality: Playa El Pulpo (2701' 22” S; 70 48’ 30” W), Comuna de Caldera, Región de

282 Atacama, Chile, intertidal under sunken rocks in rocky coast, $1 \mathrm{~m}$ depth, 29 December 2012, 283 coll. \& leg. JF Araya.

284 Diagnosis: Intertidal Berthella species with a dark brown-reddish shell decorated with pale

285 radial lines; visible through the translucent yellowish mantle, with an oval and slightly crenulated 286 margin and very small tubercles covering the notum.

287 Description: Body reaching lengths up to $25 \mathrm{~mm}$ in fully extended living specimens (Figs. 3A, 288 3B, 6C). Body uniformly pale yellowish, translucent; with an internal shell of brownish-reddish color, visible through the mantle. Mantle with a smooth appearance, but with very small

290

291

292

293

294

295

296

297

298

299

300

301

302

303

304

305

306

307

308

tubercles covering the dorsum which gives the animal, at high magnification, a somewhat wrinkled appearance. The mantle processes do not show obvious spicules. Dark and minute eyes located behind the base of the rhinophores, hidden beneath the anterior edge of the mantle (Fig. 3B). Notum wide, oval and slightly crenulated, with a broad free margin around. Gill and foot covered by the notum in living specimens, and oral veil and rhinophores partially covered in their posterior part. Mantle lacking an anterior notch. Rhinophores short and stout, joined together at the base. Foot bilabiate anteriorly. Oral veil trapezoidal, protruding from the mantle. Gill located on the right side of the body, lying longitudinally between the mantle and the foot; it is attached to the body for more than half of its length. Gill bipinnate, with 13 pinnae on either side of the rachis. Rachis smooth, lacking tubercles. Anus located dorsal to the central area of the gill. Egg masses are small white spiral ribbons, up to about $25 \mathrm{~mm}$ in diameter (Fig. 6C).

Shell: Shell fully internal, flattened, rectangular/oval in shape, elongate and located centrally in the dorsal area, where it covers completely the viscera. Shell reddish brown in color, somewhat nacreous/iridescent, with radial rays of pale yellowish which are visible through the mantle in living specimens. Margins of shell sharp and fragile. Protoconch of about $300 \mu \mathrm{m}$ in diameter, smooth under low magnification. Teleoconch with fine concentric ridges crossed by very fine radial striae, the first whorls have a cancellated sculpture (Fig. 3C). Radula: Radular formula: 50-53 x 45-56.0.45-56. Radular teeth hook-shaped lacking denticles (Fig. 4A). Innermost lateral teeth slightly smaller than those from the middle portion of the half row (Fig. 
309

310

311

312

313

314

315

316

317

318

319

320

321

322

323

324

325

326

327

328

329

330

331

332

333

334

335

336

337

338

339

4B).Outermost lateral teeth with a much more elongate cusp than the mid laterals (Fig. 4C). Jaws with elongate cruciform elements rather slender, elongate and lanceolate with a narrower base; each element consisting of a central cusp flanked by 2-3 denticles on either side of a prominent central cusp (Fig. 4D). Reproductive system: The ampulla is long and muscular, merging proximally into the female gland complex. The penis is wide, with an elongate tip; it connects proximally into a short deferent duct that splits into the prostate and the elongate, muscular penial gland. The prostate is convoluted and connects proximally to the female gland complex. A small, unidentified glandular structure connects distally into the prostate and is here referred to provisionally as prostatic gland (prg? in Fig. 5a). The vagina is elongate, straight; it narrows and connects to the round and large bursa copulatrix. The seminal receptacle is elongate, muscular and about twice as long as the bursa copulatrix; it connects to the vagina before it enters the bursa copulatrix. A uterine duct could not be observed (Fig. 5).

Habitat: This species is found exclusively under rocks sunken at low tide in an almost infaunal habitat; it can be found associated to encrusting sponges, bryozoans, encrusting algae and to communities of micromollusks including Acar pusilla (Sowerby, 1833), Brachidontes granulata (Hanley, 1843), Liotia cancellata Gray, 1848 and Mitrella unifasciata (Sowerby, 1832).

Distribution: This species is somewhat rare but broadly distributed in the area of study; small populations were found only in four localities, in about $40 \mathrm{~km}$ of coast, always under rocks. According to Schrödl (2003) this genus has records in southern South America from the southernmost Patagonian shelf (Burdwood Bank), south-eastern Atlantic Ocean to southern Chile and north to Quiriquina Island, central Chile. The genus thus extends its distribution in Chile more than $1100 \mathrm{~km}$ to the north.

Etymology: Named in honor of Michael Schrödl (Zoologische Staatssammlung München, Munich, Germany), for his extensive contributions to the Chilean opisthobranchs.

Remarks: Of the 16 valid species of Berthella known worldwide (Hermosillo \& Valdés, 2008), only two have been reported for southern South America: Berthella patagonica (d'Orbigny, 1837) and Berthella platei (Bergh, 1898). The western Atlantic Berthella patagonica, distributed from Central Argentina to Peninsula Valdés, southern Argentina (Schrödl, 2003), differs from the new species in having smaller body dimensions, with a very narrow free mantle rim and a notum apparently lacking a porous texture and not covering completely the foot which, in contrast to the new species, has a quadrangular outline (Schrödl, 1999, 2003). The Magellanic 
340 Berthella platei, distributed from the Burdwood Bank, southeastern Atlantic Ocean to Quiriquina

341 Island, Central Chile (Schrödl, 1999), differs from the new species in having a more translucent

342 body, of uniform pale pink to pale orange or whitish coloration of living animals (Fig. 6A, 6B), a

343 higher number (15-24) of branchial lamellae versus 11-14 in B. schroedli sp. n. and a paler

344 internal shell, translucent brown to greyish in color, in contrast to the characteristic reddish-

345 brown shell with faint whitish axial streaks of the new species. The radular formula and the

346 elements of the jaws also differ; Berthella schroedli sp. n. have fewer radular rows and less teeth

347 per half row than B. platei, and it has also larger elongate and lanceolate elements with a

348 narrower base and thin denticles, while $B$. platei have smaller and more triangular elements with

349 a broader base and slightly broader denticles (see Schrödl, 1999). The shell length in relation to

350 the body size in B. schroedli is also comparatively larger than in B. platei. In regard to their

351 habitat; the new species has been found almost solely under sunken rocks in relatively shallow

352 water in the intertidal; while Berthella platei is found only subtidally, living in the ocean floor

353 usually under $5 \mathrm{~m}$ depth (Dirk Schories pers. comm.). A BLAST-n of the COI sequence of $B$.

354 schroedli sp. n. returned that the most similar sequence belongs to Berthella plumula

355 (AY345025) and is only 84\% identical. The sequence of $B$. schroedli sp. n. is only $83 \%$ identical

356 to a sequence of Berthella platei (FJ917492), providing additional evidence that this species is

357 distinct.

$358 \quad$ Other Eastern Pacific species of Berthella include Berthella agassizi (MacFarland, 1909);

359 Berthella californica (Dall, 1900); Berthella grovesi Hermosillo \& Valdés, 2008; Berthella

360 martensi (Pilsbry, 1896); Berthella stellata (Risso, 1826) and Berthella strongi (MacFarland,

361 1966). All these species differ from Berthella schroedli sp. n. in their subtidal rather than

362 intertidal habitat, and also chiefly in their external coloration, by having opaque white spots $(B$.

363 agassizii, B. strongi) or light brown spots and/or an orange body with dark brown lines and spots

364 (B. martensi), a marginal notal band (B. californica), dark spots in the middle of thick opaque

365 white ringlets (B. grovesi) or a dorsal streak of white running perpendicularly across the notum,

366 which is translucent white or honey colored (B. stellata).

367

368 Order Sacoglossa Ihering, 1876

369 Superfamily Limapontioidea Gray, 1847

370 Family Hermaeidae Adams \& Adams, 1854 
371 Genus Aplysiopsis Deshayes, 1853

372 Type species Aplysiopsis elegans Deshayes, 1853, by monotypy.

373

374

Aplysiopsis cf. brattstroemi (Marcus, 1959)

375 (Fig. 2B)

376 Hermaeina brattstroömi Marcus, 1959: 21, figs. 21-27. Aplysiopsis brattstroemi Schrödl, 1996a:

377 45, pl. VIII, fig.52; Fischer \& Cervera, 2005: 167; Jensen, 2007: 279.

378 Material examined: One specimen photographed alive (not collected); on filamentous algae in 379 tidal pool at very low tide, Playa Brava (2703' S; 7049' W), Caldera, Región de Atacama, 380 Chile.

381 Diagnosis: Body minute, up to about $5 \mathrm{~mm}$ in examined specimen, with an elongated body, 382 narrowed anteriorly; of brown to deep greenish-black color, with two clear areas at the sides of 383 the head. Several rows of flat longitudinal cerata in the border of the mantle. Enrolled 384 rhinophores. Size up to about $3 \mathrm{~cm}$ (See Marcus (1959) for a complete description).

385 Distribution: Aplysiopsis brattströmi has a discontinuous distribution from Antofagasta (2339' $386 \mathrm{~S} ; 7^{\circ} 25^{\prime} \mathrm{W}$ ), to Bahia de Coliumo (36 $32^{\prime}$ S; 7257' W) in Chile (Schrödl, 1996a). The definite 387 allocation of this species is currently not possible as, unfortunately, it was not collected.

388

389

390

391

392

393

394

395

396

397

398

399

400

401
Order Systellommatophora Pilsbry, 1948

Superfamily Onchidioidea Rafinesque, 1815

Family Onchidiidae Rafinesque, 1815

Genus Onchidella J. E. Gray, 1850

Type species Onchidium nigricans Quoy \& Gaimard, 1832, by subsequent designation by Fischer and Crosse (1878).

\section{Onchidella marginata (Couthouy in Gould, 1852)}

(Fig. 2C)

Peronia marginata Couthouy in Gould, 1852: 292; Atlas, 1856: pl. 22, figs. 386a-c. Onchidium chilense Gay, 1854: 120. Onchidella marginata Marcus, 1959: 16, figs. 17-20. Dayrat, 2009: 13. Rosenfeld \& Aldea, 2010: 35, figs. 1A-B. A more complete synonymy can be found in Dayrat (2009). 
402 Material examined: Ten specimens collected under small rock slabs at low tide, Playa El Pulpo 403 (2703’ S; 7049’ W), Caldera, Región de Atacama, Chile (MZUC 280316).

404 Diagnosis: Body elongate ovate, narrowed anteriorly; back very convex, deep greenish-black,

405 very thickly covered with minute tubercles; margin ornamented with alternate bars of black and 406 white; head broad, bilobed in font, and projecting considerably beyond the mantle when the 407 animal is in motion, of a pale yellow color, tinted bluish about the mouth; tentacles rather long, 408 and bulbous at the extremity, pale slate-color, except at the tips, which are back; under side of 409 the mantle pale yellowish, becoming greenish at the margin, where it shows alternate bands of 410 green and pale yellow (See Gould (1852) for a complete description).

411 Distribution: Onchidella marginata has a discontinuous distribution from Iquique $\left(20^{\circ} \mathrm{S}\right)$ to the 412 Magallanes Strait $\left(55^{\circ} \mathrm{S}\right)$ in Chile, and to the Isla de los Estados in the South Atlantic of 413 Argentina (Rosenfeld \& Aldea, 2010).

414 Remarks: This is the only pulmonate sea slug found in Chile (Valdovinos, 1999; Dayrat, 2009);

415 it is usually found in small communities living under rocks and camouflaging against their 416 surroundings. In the area under study this species share its habitat with other molluscs as the 417 limpet Lottia orbignyi (Dall, 1909), and the chitons Chaetopleura peruviana (Lamarck, 1819) 418 and Radsia barnesi (Gray, 1828).

419

420

\section{DISCUSSION}

421 The present work updates the knowledge on the scarcely known marine fauna of northern Chile 422 (in particular from the Región de Atacama); from the 65 species of sea slugs (only including 423 Nudibranchia and Pleurobranchoidea) recorded to live in Chilean waters (Schrödl, 2003), eight 424 species were recorded in the Región de Atacama, accounting for about $12 \%$ of the Chilean sea 425 slug fauna. All of the species occurring in the area have widespread ranges in the southeastern 426 Pacific Ocean, from Ancash, Peru to the Strait of Magellan, in southern Chile and in the South 427 Atlantic Ocean, to Peninsula Valdés, in Argentina (Table 1). With the exception of Berthella 428 schroedli sp. n., all of the species found in the Región de Atacama also occur in central and 429 southern Chile. The absence of species previously cited for the area (Schrödl, 1996a, 2003; 430 Schrödl \& Hooker, 2014), for example Corambe lucea Marcus 1959; Janolus rebeccae Schrödl, 431 1996; Okenia luna Millen, Schrödl, Vargas \& Indacochea, 1994 and Thecacera darwini Pruvot- 
432 Fol, 1950, among others, could be explained due to the limit of sampling depth, which was

433 restricted to the lower intertidal areas with a maximum of $2 \mathrm{~m}$ depth.

434 Heterobranch sea slugs have been rarely treated in studies reviewing the biodiversity of

435 mollusks from northern Chile (e.g. Marincovich, 1973; Guzmán et al. 1998), despite the

436 comparatively high number of species recorded in the country. This is in part explained by the

437 current lack of experts working actively in the field and the difficulties involved in collecting and

438 preserving marine slugs. The finding of a new species of Berthella in northern Chile also

439 highlights the need of further studies in the area or in northern Chile in general, which have

440 recently revealed new invertebrate species (Reiswig \& Araya, 2013; Collado, 2015) or new

441 distributions for obscure or rare species, both from shallow and deeper waters (e.g. Araya \&

442 Aliaga, 2015; Araya \& Araya, 2015b; Araya, Aliaga \& Araya, 2015; Araya, 2015c; Fischer, van

443 der Velde \& Roubos, 2007; Labrín, Guzmán \& Sielfeld, 2015).

444

445 ACKNOWLEDGMENTS

446 We are very grateful to Marta Araya (Caldera, Chile) for her assistance in field collecting, to

447 Carlo Magenta Cunha (Academy of Natural Sciences of Drexel University, Philadelphia, USA),

448 and to Cecilia Osorio (Universidad de Chile, Santiago, Chile) for their help with essential

449 bibliography, to Dirk Schories (University of Rostock, Rostock, Germany) for his help with the

450 images and information on Berthella platei from southern Chile and to Michael Schrödl

451 (Zoologische Staatssammlung München, Germany) and two anonymous reviewers for their

452 helpful corrections and suggestions on the manuscript.

453

454

455

456

457

458

459

460

461

\section{REFERENCES}

Abraham PS. 1877. Revision of the anthobranchiate nudibranchiate Mollusca, with descriptions or notices of forty-one hitherto undescribed species. Proceedings of the Zoological Society of London, 1877:196-269.

Álamo V, Valdivieso V. 1997. Lista sistemática de moluscos marinos del Peru. Segunda edición, revisada y actualizada. Publicación Especial Instituto del Mar del Perú, 183 pp.

Aldea C, Césped T, Rosenfeld, S. 2011. Opisthobranchs from Bernardo O’Higgins National Park (S. Chile). Thalassas 27(2):37-48. 
462

463

464

465

466

467

468

469

470

471

472

473

474

475

476

477

478

479

480

481

482

483

484

485

486

487

488

489

490

491

492

Araya JF. 2013. A new species of Aeneator Finlay, 1926 (Mollusca, Gastropoda, Buccinidae)

from northern Chile, with comments on the genus and a key to the Chilean species.

ZooKeys 257:89-101 DOI 10.3897/zookeys.257.4446

Araya JF. 2015a. Current status of the non-indigenous molluscs of Chile, with the first record of Otala punctata (Müller, 1774) (Gastropoda: Helicidae) in the country and new records for Cornu aspersum (Müller, 1774) and Deroceras laeve (Müller, 1774). Journal of Natural History 49:1731-1761 DOI 10.1080/00222933.2015.1006703.

Araya JF. 2015b. The Bulimulidae (Mollusca: Pulmonata) from the Región de Atacama, northern Chile. PeerJ 3:e1383 DOI 10.7717/peerj.1383

Araya JF. 2015c. New records of deep-sea sea spiders (Chelicerata: Pycnogonyda) in the southeastern Pacific. Marine Biodiversity DOI 10.1007/s12526-015-0416-7

Araya JF, Aliaga JA. 2015. The northernmost record of Tytthosoceros inca Baeza, Véliz, Pardo, Lohrmann and Guisado 1997 (Plathyhelminthes: Pseudocerotidae) in Chile. Marine Biodiversity DOI 10.1007/s12526-015-0395-8

Araya JF, Aliaga JA, Araya ME. 2015. On the distribution of Physalia physalis (Hydrozoa: Physaliidae) in Chile. Marine Biodiversity DOI 10.1007/s12526-015-0417-6

Araya JF, Araya ME. 2015a. The shallow-water chitons (Mollusca, Polyplacophora) of Caldera, Region of Atacama, northern Chile. Zoosystematics and Evolution 91(1):45-58 DOI $10.3897 /$ zse.91.8536

Araya JF, Araya ME. 2015b. The southernmost record of the amphipod Hyperia curticephala (Crustacea: Amphipoda: Hyperiidae) in the Pacific Ocean. Marine Biodiversity Records 8:e40. DOI 10.1017/S1755267215000184

Araya JF, Catalán R. 2014. A review of the non-bulimulid terrestrial Mollusca from the Region of Atacama, northern Chile. ZooKeys 398: 33-51 DOI 10.3897/zookeys.398.4282

Araya JF, Reid DG. 2016. A new species of Echinolittorina Habe, 1956 (Gastropoda:

Littorinidae), from a Quaternary shallow water molluscan assemblage in northern Chile.

Palaeontologia Electronica 19.1.8A: 1-8

Bergh LSR. 1867. Phidiana lynceus og Ismaila monstrosa. Videnskabelige Meddeleser fra Danske Naturhistorisk Forening 97-130.

Bergh LSR. 1898. Die Opisthobranchier der Sammlung Plate. Zoologische Jahrbücher, Supplement 4(3):481-582. 
493

494

495

496

497

498

499

500

501

502

503

504

505

506

507

508

509

510

511

512

513

514

515

516

517

518

519

520

521

522

523

Broderip WJ, Sowerby GB. 1832. [Description of new (...) Mollusca and Conchifera (...) part of the collection made by Mr. H. Cuming]. Proceedings of the Zoological Society of London 1832:25-33.

Camacho-García Y, Pola M, Carmona L, Padula V, Villani G, Cervera L. 2014. Diversity and distribution of the heterobranch sea slug fauna on the Caribbean of Costa Rica. Cahiers de Biologie Marine 55:109-127.

Collado GA. 2015. A new freshwater snail (Caenogastropoda: Cochliopidae) from the Atacama Desert, northern Chile. Zootaxa 3925(3):445-449.

Dall WH. 1909. Report on a collection of shells from Peru, with a summary of the littoral marine mollusks of the Peruvian zoological province. Proceedings of the United States National Museum 37:147-294.

Dayrat B. 2009. Review of the current knowledge of the systematics of Onchidiidae (Mollusca: Gastropoda: Pulmonata) with a checklist of nominal species. Zootaxa 2068:1-26.

d' Orbigny A. 1835-1843. Voyage dans l'Amérique Méridionale 5(3): Mollusques. Bertrand, Paris. Dates of publication: pp. 1-48 [1835], pp. 49-184 [1836], pp. 185-376 [1837], pp. 377-408 [1840], pp. 409-488 [1841], pp. 489-758, pls 1-85 [1846].

Fischer MA, Cervera JL. 2005a. Baptodoris peruviana (D’Orbigny, 1837) comb. nov., an alternative taxonomic placement for Doris peruviana (Gastropoda: Nudibranchia: Doridoidea). Journal of Conchology 38:513-528.

Fischer MA, Cervera JL. 2005b. Checklist of the opisthobranchs (Mollusca: Gastropoda) from the Chilean coast deposited in the "Colección de Flora y Fauna Profesor Patricio Sánchez Reyes "from the "Pontificia Universidad Católica de Chile“. Iberus 23(2):165-181.

Fischer MA, van de Velde G, Roubos EW. 2007. Morphology, anatomy and histology of a new species of Flabellina Voigt, 1834 (Opisthobranchia: Aeolidoidea) from the Chilean coast. Animal Biology 57:363-391.

Gay C. 1854. Atlas de la Historia Física y Política de Chile. Imprenta de E. Thunot y Ca. Segundo Tomo. Paris.

Gigoux EE. 1932. Sobre algunos caracoles terrestres de Atacama. Revista Chilena de Historia Natural 36(1):20-25.

Gigoux EE. 1934. Los moluscos marinos de Atacama. Revista Chilena de Historia Natural 38:274-286. 
524 Gould AA. 1852. Mollusca \& Shells. United States Exploring Expedition 12: xv + 510 pp. Gould 525 \& Lincoln: Boston.

526 Gray JE. 1850. Figures of molluscous animals, selected from various authors, etched for the use 527 of students, vol. 1-4. Longman, Brown, Green and Longmans, London.

528 Hermosillo A, Valdés A. 2008. Two new species of opisthobranch mollusks from the tropical 529 eastern Pacific. Proceedings of the California Academy of Sciences 59:521-532.

530 Hupé H. 1854. Fauna Chilena: Moluscos. Historia física y política de Chile, 95 Zoología 8: iii + 531499 pp., 14 pls. Gay: Paris.

532 Jensen KR. 2007. Biogeography of the Sacoglossa (Mollusca, Opisthobranchia). Bonner 533 zoologische Beiträge 55(3/4):255-281.

534 Folmer O, Black M, Hoeh W, Lutz R, Vrijenhoek, R. 1994. DNA primers for amplification of 535 mitochondrial cytochrome c oxidase subunit I from diverse metazoan invertebrates.

536 Molecular Marine Biology and Biotechnology 3:294-299.

537 Kearse M, Moir R, Wilson A, Stones-Havas S, Cheung M, Sturrock S, Buxton S, Cooper A, 538 Markowitz S, Duran C, Thierer T, Ashton B, Mentjies P, Drummond A. 2012. Geneious 539 Basic: an integrated and extendable desktop software platform for the organization and analysis of sequence data. Bioinformatics 28:1647-1649.

Labrín M, Guzmán G, Sielfeld W. 2015. Pterópodos thecosomados en el Pacífico suroriental frente a Caldera, Chile (Mollusca, Opistobranchiata: Euthecostomata y Pseudothecostomata). Latin American Journal of Aquatic Research 43(1):71-79.

Lesson RP. 1831. Voyage autour du monde execute par ordre du roi sur la corvette de sa 545 Majesté, La Coquille, pendant les années 1822, 1823, 1824 et 1825. Zoologie 2:239-455.

MacFarland FM. 1909. The opisthobranchiate Mollusca of the Branner-Agassiz expedition to Brazil. Letland Stanford Junior University Publications 2:1-104.

MacFarland FM. 1966. Studies of opisthobranch mollusks of the Pacific coast of North America. Memoirs California Academy of Sciences 6:1-546.

Marcus E. 1959. Reports of the Lund University Chile Expedition 1948-49. 36. Lamellariacea und Opisthobranchia. Lunds Universitets Arsskrift (NF) 55:1-135.

552 Marcus E, Marcus E. 1967. American opisthobranch mollusks. Institute of Marine Sciences, 553 Miami. 256 pp. 
554 Martynov A, Schrödl M. 2011. Phylogeny and evolution of corambid nudibranchs (Mollusca:

555 Gastropoda). Zoological Journal of the Linnean Society 163:585-604.

556 Millen S, Schrödl M, Vargas N, Indacochea A. 1994. A new species of Okenia (Nudipleura:

557 Doridacea) from the Peruvian faunal province. The Veliger 37:312-318.

558 Miquel SE, Araya JF. 2013. A new Charopidae from Chile and Argentina, Stephacharopa

559 calderaensis n. gen. and n. sp., with remarks on the taxonomy of the genus Stephadiscus

560 Hylton Scott 1981 (Mollusca: Gastropoda Pulmonata). Archiv für Molluskenkunde

$561 \quad 142(2): 227-235$.

562 Muniaín C, Valdés A, Ortea J. 1996. Redescription of Tyrinna nobilis Bergh, 1898

563 (Opisthobranchia: Chromodorididae) from Patagonia, Argentina. Journal of Molluscan

564 Studies 62(3):265-273.

565 Nakamura K. 2006. New records of opistobranch mollusks from the Guayaquil marine

566 ecoregion: northern Perú. The Festivus 38:75-83.

567 Nakamura K. 2007. Especies bentónicas de Opisthobranchia (Mollusca: Gastropoda) presents en 568 el litoral del norte peruano. Revista Peruana de Biología 13(3):255-257.

569 Odhner NH. 1926. Die Opisthobranchien. Further Zoological Results of the Swedish Antarctic $570 \quad$ Expedition 1901-1903 2:1-100.

571 Osorio C. 2012. Nueva especie del género Liotia (Gastropoda: Trochoidea: Liotiidae) del

572 Pacífico sur oriental, norte de Chile. Revista de Biología Marina y

$573 \quad$ Oceanografía 47(3):407-411.

574 Philippi RA. 1860. Viage [sic] al Desierto de Atacama, hecho de orden del Gobierno de Chile 575 en el verano 1853-54. Halle en Sajonia, 254 pp.

576 Pilsbry HA. 1895-1896. American bulimi and bulimuli. Strophocheilus, Plekocheilus, Auris, 577 Bulimulus. Manual of Conchology (2)10:1-213.

578 Rehder HA. 1945. The Chilean species of the molluscan genus Peronaeus (Bulimulidae). Revista 579 Chilena de Historia Natural 48(1):102-107.

580 Reiswig H, Araya JF. 2014. A review of the Hexactinellida (Porifera) of Chile, with the first 581 record of Caulophacus Schulze, 1885 (Lyssacinosida: Rossellidae) from the Southeastern Pacific Ocean. Zootaxa 3889(3):414-428. DOI 10.11646/zootaxa.3889.3.4.

Risso A. 1826-1827. Histoire naturelle des principales productions de l'Europe Méridionale et particulièrement de celles des environs de Nice et des Alpes Maritimes. Paris, Levrault: 
585

586

587

588

589

590

591

592

593

594

595

596

597

598

599

600

601

602

603

604

605

606

607

608

609

610

611

612

613

614

615

Vol. 1: XII $+448+1$ carta [1826]. Vol. 2: VII $+482+8$ pl. (fiori) [novembre 1827]. Vol.

3: XVI $+480+14$ pl. (pesci) [settembre 1827]. Vol. 4: IV $+439+12$ pl. (molluschi)

[novembre 1826]. Vol. 5: VIII $+400+10$ pl.

Rosenfeld S, Aldea C. 2010. Onchidella marginata (Couthouy en Gould, 1852): antecedentes de la especie. Amici Molluscarum 18:35-37.

Schrödl M. 1996a. Nudibranchia y Sacoglossa de Chile: Morfología exterior y distribución. Gayana 60:17-62.

Schrödl M. 1996b. Janolus rebeccae, a new species of arminacean nudibranchs from northern Chile. Spixiana 19(3):293-300.

Schrödl M. 1997. Range extensions of Magellanic Nudibranchs (Opisthobranchia) into the Peruvian faunal province. The Veliger 40:38-42.

Schrödl M. 1999. The genus Berthella Blainville, 1825 (Notaspidea, Pleurobranchidae) from Magellanic waters. Journal of Molluscan Studies 65:399-409.

Schrödl M. 2000a. Revision of the nudibranch genus Cadlina (Gastropoda: Opisthobranchia) from the Southern Ocean. Journal of the Marine Biological Association of the United Kingdom 80:299-309.

Schrödl M. 2000b. Taxonomic revision of the common South American nudibranch Anisodoris fontaini (d'Orbigny, 1837), with discussion of its systematic placement. Journal of Molluscan Studies 66:49-61.

Schrödl M. 2003. Sea slugs of Southern South America. Conch Books, Hackenheim, 165 pp.

Schrödl M. 2009. Opisthobranchia - Sea Slugs. Pp. 505-542 in: Häussermann, V. \& Försterra, G. (eds). Fauna Marina Bentónica de la Patagonia Chilena. Chile (Nature in Focus).

Schrödl M, Grau JH. 2006. Nudibranchia from the remote southern Chilean Guamblin and Ipún Islands (Chonos Archipelago, 44-45으, with redescription of Chilean Rostanga pulchra MacFarland, 1905. Revista Chilena de Historia Natural 79:3-12.

Schrödl M., Hooker Y. 2014. Sea slugs of Peru: Peruvian-Chilean faunal elements. Spixiana 37(1):45-59.

Schrödl M, Millen SV. 2001. Revision of the nudibranch gastropod genus Tyrinna Bergh, 1898 (Nudibranchia: Doridoidea). Journal of Natural History 35:1143-1171.

Schrödl M, Alarcón MA, Bedriñana LR, Bravo FJ, Bustamante CM, Carvalho R, Försterra G, Häussermann V, Salmen A. 2005. Nudipleura (Gastropoda: Opisthobranchia) from the 
616

617

618

619

620

621

622

623

624

625

626

627

628

629

630

631

632

633

634

635 southern Chilean Comau Fjord, with redescription of Polycera priva Marcus, 1959. Vita Malacologica 3:23-33.

Sowerby GB II (1840) Pp. 25-33, 50-61, 104-108, 124-126 [1832]; 173-179, 194-202 [1833]. In: WJ Broderip \& GB Sowerby I (eds.), 1832-1833. Characters of new species of Mollusca and Conchifera, collected by Mr. Cumming. Proceedings of the Malacological Society of London for 1832, 1833.

Uribe RA, Pacheco AS. 2012. First record of Spurilla neapolitana (Mollusca: Nudibranchia: Aeolidiidae) on the central coast of Peru (Humboldt Current Upwelling Ecosystem). Marine Biodiversity Records 5:e14.

Uribe RA, Nakamura K, Indacochea A, Pacheco AS, Hooker Y, Schrödl M. 2013. A review on the diversity and distribution of opisthobranch gastropods from Peru, with the addition of three new records. Spixiana 36(1):43-60.

Valdés A, Gosliner TM. 2001. Systematics and phylogeny of the caryophyllidia-bearing dorids (Mollusca, Nudibranchia), with descriptions of a new genus and four new species from Indo-Pacific deep waters. Zoological Journal of the Linnean Society 133(2):103-198.

Valdés A, Muniaín C. 2002. Revision and taxonomic reassessment of Magellanic species assigned to Anisodoris Bergh, 1898 (Nudibranchia: Doridoidea). Journal of Molluscan Studies 68:345-351.

Valdovinos C. 1999. Biodiversidad de moluscos chilenos: Base de datos taxonómica y distribucional. Gayana 63(2):111-164. 
1

Species of heterobranch sea slugs found near Caldera, Atacama region, northern Chile (all specimens photographed in situ).

(A) Phidiana lottini (Lesson, 1831), Calderilla Beach, inside a valve of Argopecten purpuratus (Lamarck, 1819), L= 23 mm; (B) Tyrinna delicata (Abraham, 1877), Obispito Bay, L= $10 \mathrm{~mm}$; (C) Baptodoris peruviana (d'Orbigny, 1837), Ramada Beach, L= 23 mm; (D) Diaulula variolata (d'Orbigny, 1837), El Pulpo Beach, L= $34 \mathrm{~mm}$.
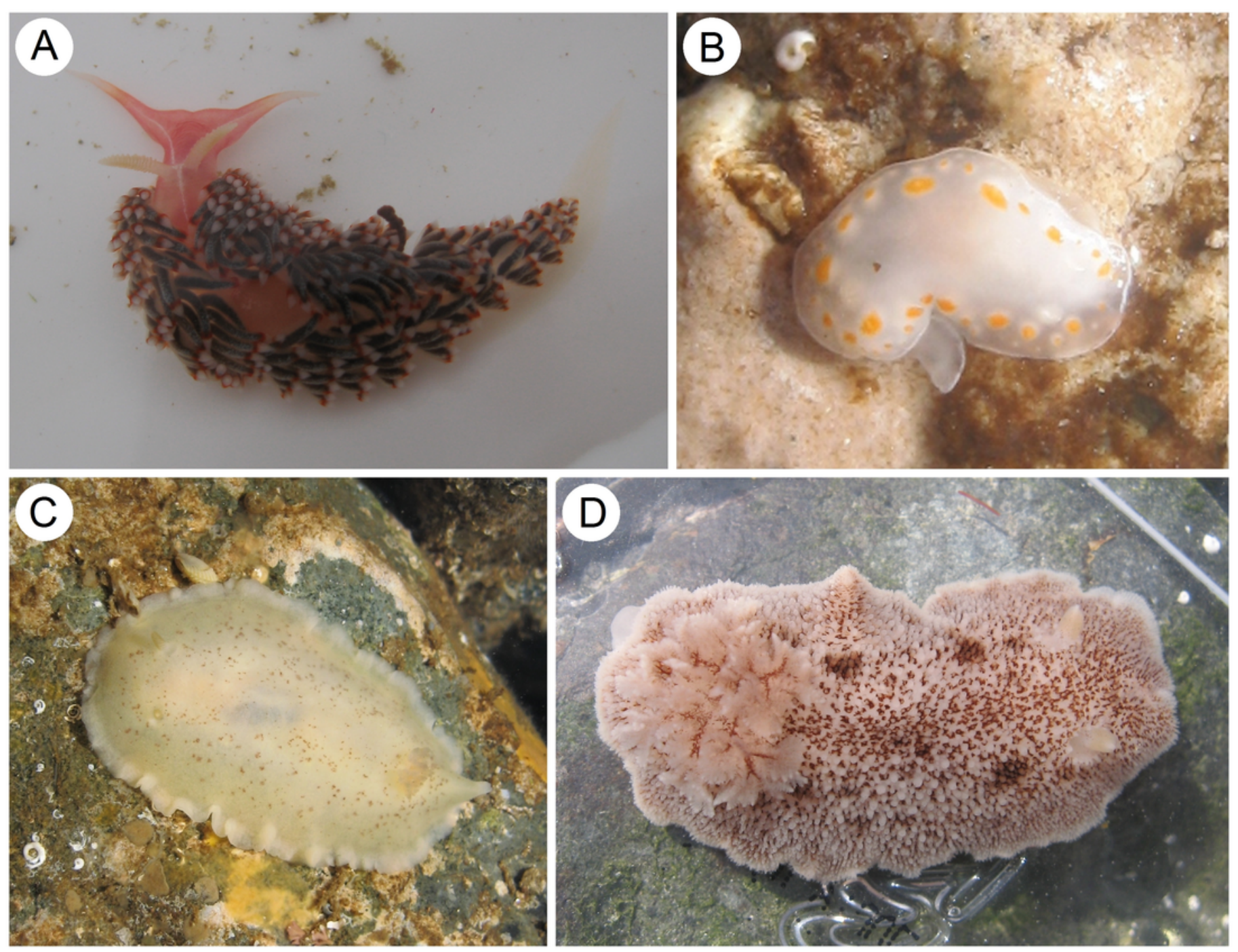
2

Species of heterobranch sea slugs found near Caldera, Atacama region, northern Chile (all specimens photographed in situ)

A) Doris fontainii d'Orbigny, 1837, Playa El Jefe, L = 54 mm; B) Aplysiopsis cf. brattstroemi (Marcus, 1959), Brava Beach, specimen found among filamentous algae in tidal pool, L about $4 \mathrm{~mm}$; C) Onchidella marginata (Couthouy in Gould, 1852), Playa El Pulpo, L = $12 \mathrm{~mm}$ (largest specimen).
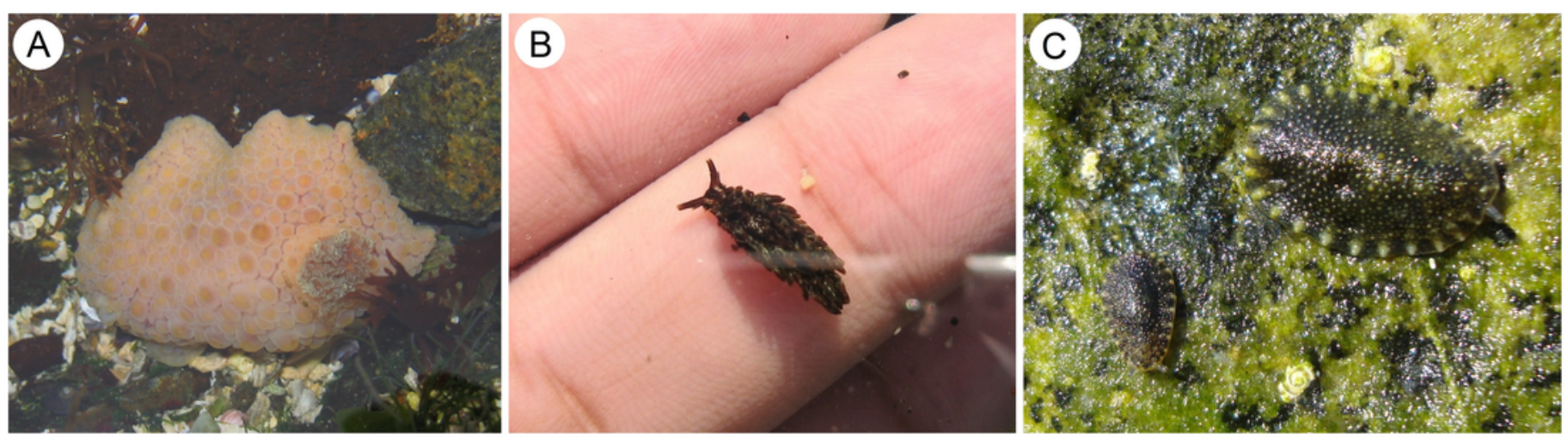
3

Berthella schroedeli sp. nov.

(A) Specimens photographed in situ, under rocks at low tide, Aguas Verdes; (B). Detail of specimen showing the eyes; (C) SEM image of shell (LACM 3327).

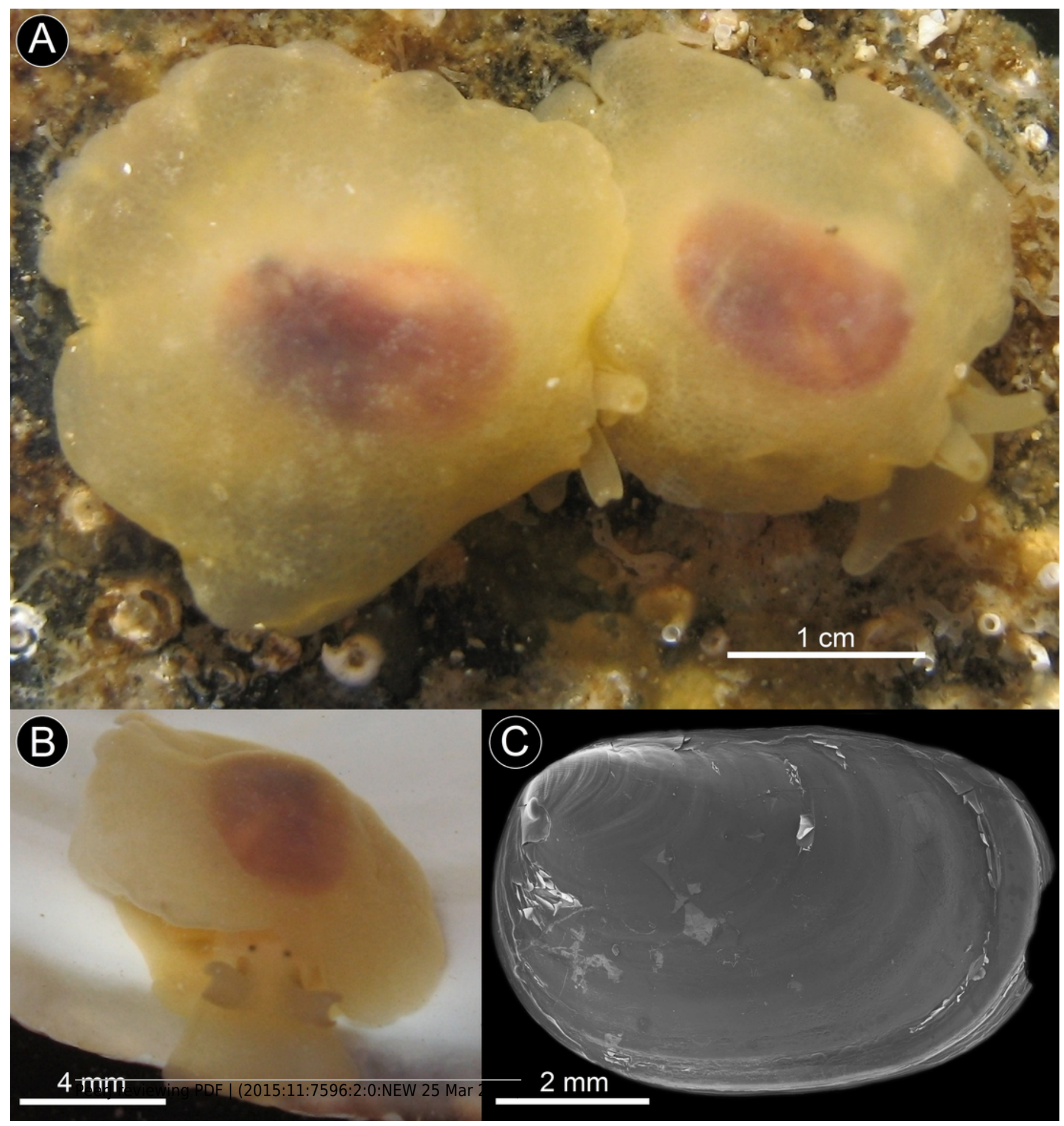


4

Berthella schroedeli sp. nov., SEM images (LACM 3327).

(A) Radular teeth, central portion of the radula; (B) Outermost radular teeth; (C) Lateral teeth, middle portion of the half row; (D) Detail of the jaw platelets.

*Note: Auto Gamma Correction was used for the image. This only affects the reviewing manuscript. See original source image if needed for review. 


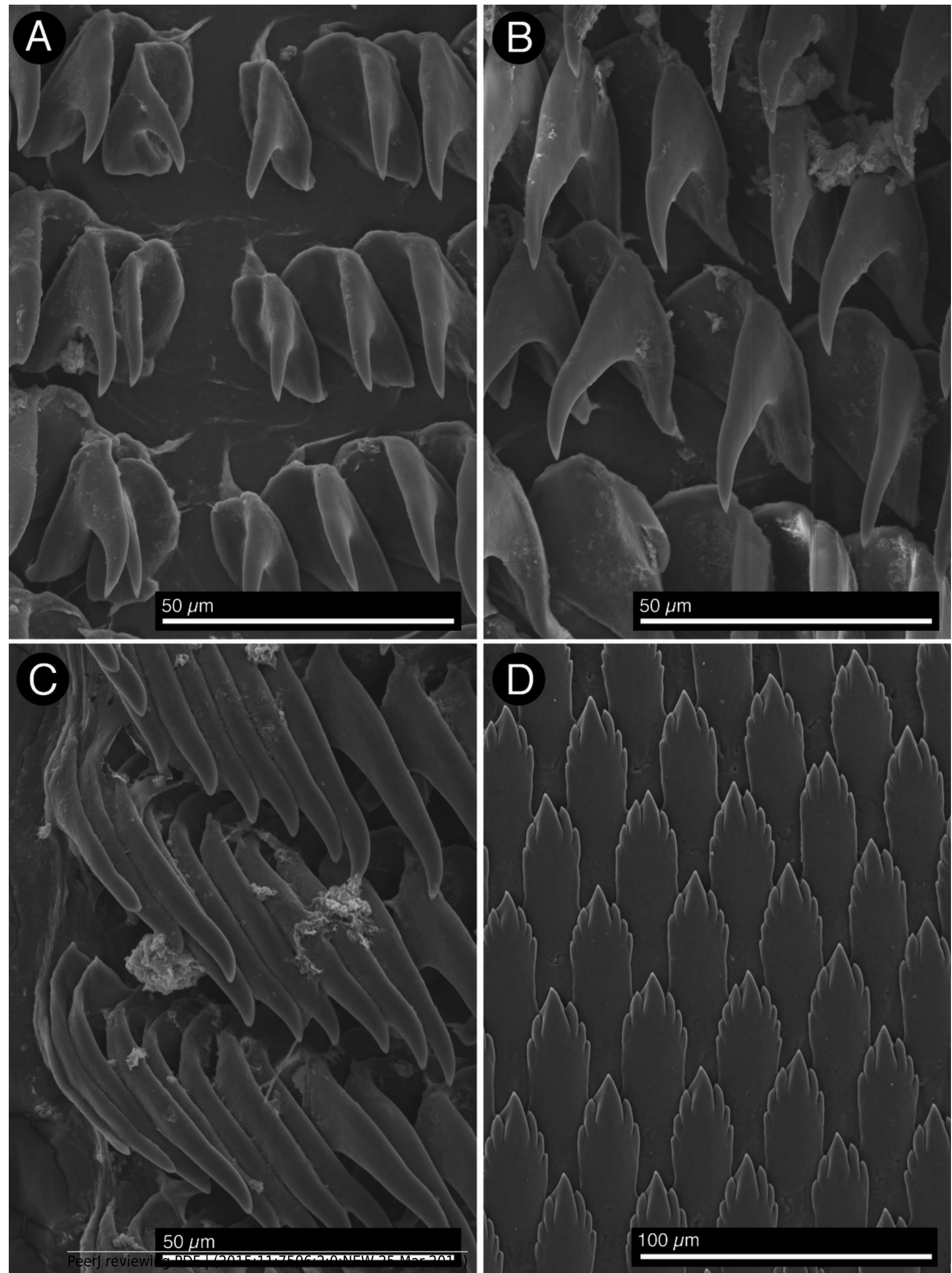




\section{5}

Reproductive anatomy of Berthella schroedli sp. nov.

(A) Dorsal view of the reproductive system; (B) Detail of some organs covered by the prostate and penial gland. Abbreviations used are: am, ampulla; bc, bursa copulatrix; fgc, female gland complex; pe, penis; pg, penial gland; pr, prostate; sr, seminal receptacle; vg, vagina. 


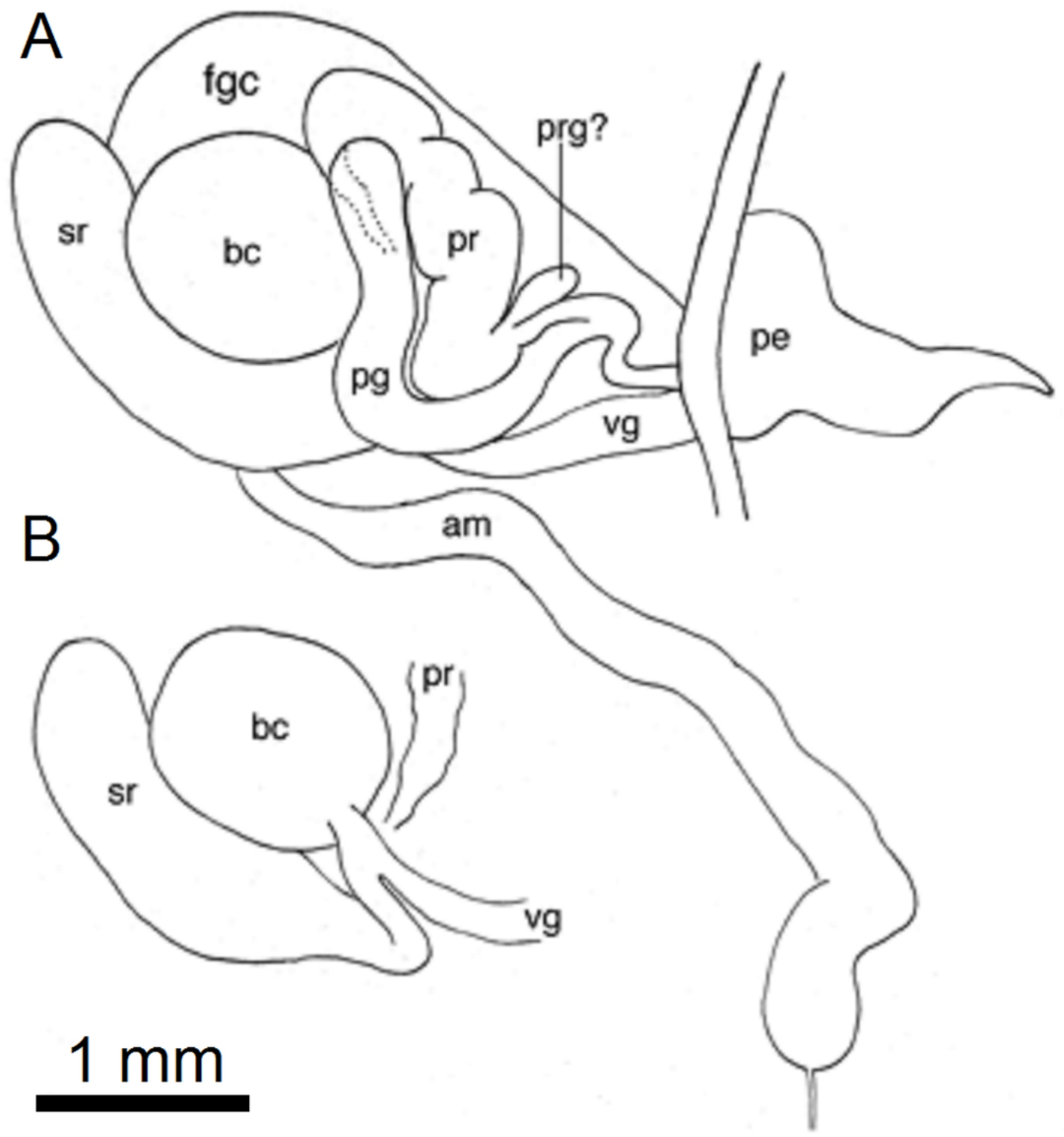




\section{6}

Chilean Berthella species

(A) and (B) specimens of Berthella platei (Bergh, 1898) photographed in situ, Caleta de Arena, 20 m depth and Valdivia respectively (photos B and C courtesy of Dirk Schories); C) Berthella schroedli sp. nov., specimen sitting on egg masses, Obispito, Caldera.

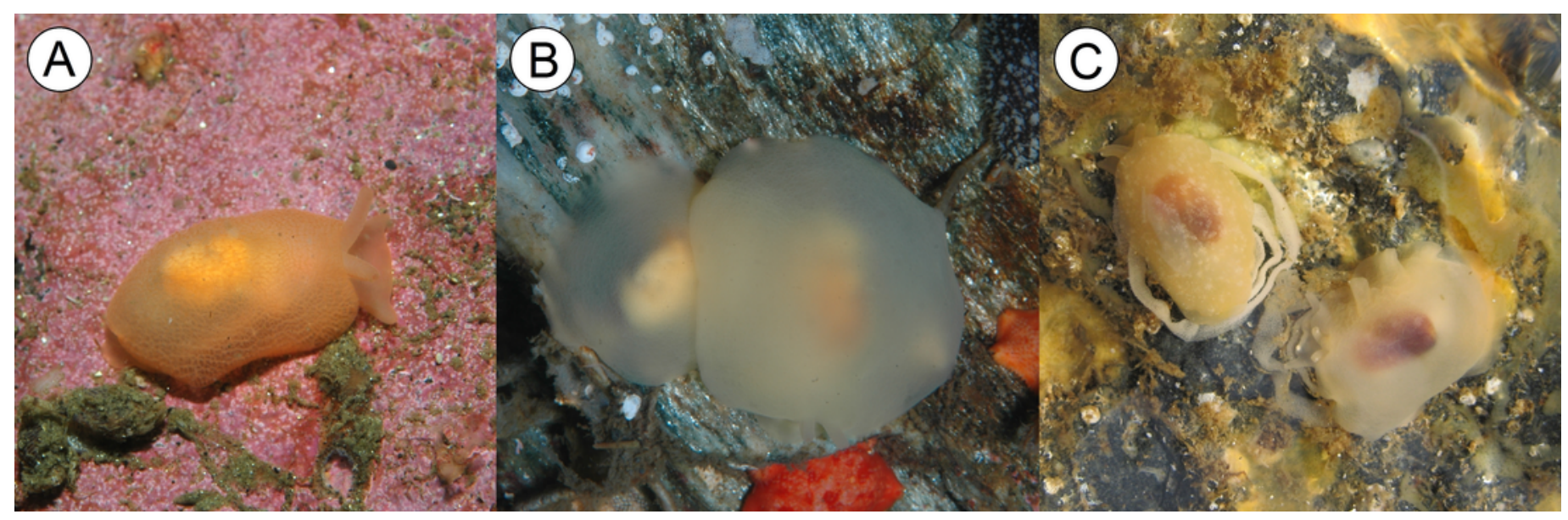




\section{Table $\mathbf{1}$ (on next page)}

Heterobranch sea slugs found in the Region of Atacama, northern Chile; species, distribution, ecology and references.

Occurring species involve those cited by Marcus (1959), Schrödl (1996a, 2003), and material examined in this work. 
1 Table 1. Heterobranch sea slugs found in the Region of Atacama, northern Chile; species, 2 distribution, ecology and references. Occurring species involve those cited by Marcus (1959), 3 Schrödl (1996a, 2003), and material examined in this work.

4

Species

Aplysiopsis cf. brattstroemi (Marcus, 1959)

Baptodoris peruviana (d'Orbigny, 1837)

Berthella schroedli sp. n.

Diaulula variolata (d'Orbigny, 1837)

Doris fontainii (d'Orbigny, 1837)

Onchidella marginata (Couthoy in Gould, 1852)

Phidiana lottini (Lesson, 1831)

Tyrinna delicata Abraham, 1877

\section{Distribution \\ Antofagasta (2339' S; $\left.70^{\circ} 25^{\prime} \mathrm{W}\right)$ to Bahia de Coliumo (36 $32^{\circ}$ ' S; $\left.72^{\circ} 57^{\prime} \mathrm{W}\right)$, Chile San Lorenzo $\left(12^{\circ} \mathrm{S}\right)$, Peru to Valparaiso, Chile ( $\left.33^{\circ} 02^{\prime} \mathrm{S}, 71^{\circ} 38^{\prime} \mathrm{W}\right)$ Caldera $\left(27^{\circ} \mathrm{S}\right)$, Chile}

Ica $\left(14^{\circ} \mathrm{S}\right)$, Perú to Bahía de San Vicente $\left(36^{\circ} \mathrm{S}\right)$, Chile Islote Ferrol ( $09^{\circ} 08^{\prime} 22^{\prime \prime}$ S; 78 37'15” W), Ancash, Peru to northern Argentina. Iquique $\left(20^{\circ} \mathrm{S}\right)$, Chile to Isla de los Estados (coordinates), Argentina Callao (12 $02^{\prime}$ S), Peru to Comau Fjord $\left(42^{\circ} 15^{\prime} \mathrm{S}\right.$; $\left.72^{\circ} 25^{\prime} 12^{\prime} \mathrm{W}\right)$, Chile.

Isla Blanca $\left(09^{\circ} \mathrm{S}\right)$, Ancash, Peru to Peninsula Valdés, in the Atlantic Magellan Strait

\section{Ecology}

Sea floor, subtidal

\section{References}

Schrödl (1996a)

Sea floor, epifaunal, subtidal (2005)

Under sunken This work

rocks, infaunal, subtidal

Sea floor, epifaunal, subdtidal

Sea floor, epifaunal, subtidal

Under rocks, Rosenfeld \& epifaunal, intertidal

Sea floor, epifaunal, subtidal

Schrödl et al. (2005), Uribe et al. (2013) and Schrödl \& Hooker (2014)

Sea floor, epifaunal, subtidal 2001 , Uribe et al . 2013. 